ARTIKEL

E-ISSN: $2615-5028$

\title{
KONTESTASI AKTOR DALAM PENGELOLAAN SUMBER DAYA PESISIR DI WILAYAH PEMBANGUNAN REKLAMASI TELUK JAKARTA
}

\author{
Eva Royandi \\ Ricardus Keiya \\ (Institut Pertanian Bogor, e.royandi@yahoo.co.id)
}

\begin{abstract}
This study discusses the locations that feel the impact of the North Coast Jakarta reclamation. The reclamation results that are seen are like reclamation in the eastern part of the luxurious Pantai Mutiara residential area, reclamation in the western part of Pantai Indah Kapuk and the construction of the Muara Angke port as access to public crossing. Using library research, this study found that the presence of this reclamation had an effect on the socio-economic conditions of the people of Muara Angke, which most people work as fishermen and other fisheries business actors such as seafood traders and processors. This study recommends that processing natural fisheries resources is an important effort in maintaining sustainability of resources (sustainability). Thus not only the current generation enjoys a wealth of resources, but future generations will feel the same.
\end{abstract}

Keywords: Development Sociology; Power Relations; Social Actor; Jakarta Bay

\begin{abstract}
Abstrak
Penelitian ini membahas tentang lokasi yang merasakan dampak reklamasi Pantai Utara Jakarta. Hasil reklamasi yang terlihat yaitu seperti reklamasi di bagian timur kawasan hunian mewah Pantai Mutiara, reklamasi di bagian barat Pantai Indah Kapuk serta dibangunnya pelabuhan Muara Angke sebagai akses penyebrangan masyarakat umum. Dengan menggunakan studi kepustakaan, kajian ini mendapati bahwa kehadiran reklamasi ini berpengaruh terhadap kondisi sosial-ekonomi masyarakat Muara Angke, yang kebanyakan masyarakat berprofesi sebagai nelayan dan pelaku usaha perikanan lainnya seperti pedagang dan pengolah hasil laut. Kajian ini merekomendasikan bahwa pengolahan sumber daya alam perikanan fisheries management) merupakan upaya penting dalam menjaga kesinambungan sumber daya (sustainability). Dengan demikian tidak saja generasi sekarang yang menikmati kekayaan sumber daya, tetapi generasi mendatang pun akan merasakan hal yang sama.
\end{abstract}

Kata Kunci: Sosiologi Pembangunan; Relasi Kuasa; Aktor Sosial; Teluk Jakarta 


\section{A. PENDAHULUAN}

Wilayah Indonesia memiliki garis pantai sepanjang $99.093 \mathrm{KM}^{2}$, terpanjang setelah Kanada, jika dilakukan pemetaan yang lebih detail, maka garis pantai Indonesia bisa bertambah sampai lebih dari $100.000 \mathrm{~km}^{2}$, dengan 3/4 wilayahnya merupakan wilayah laut dan pesisir (Kardono, 2015). Wilayah pesisir dan lautan Indonesia yang kaya dan beragam sumber daya alamnya telah dimanfaatkan oleh bangsa Indonesia sebagai salah satu sumber bahan makanan utama, khususnya protein hewani, sejak berabad-abad lamanya. Selain menyediakan berbagai sumber daya tersebut, wilayah pesisir dan lautan Indonesia juga memiliki fungsi lain, seperti transportasi dan pelabuhan, kawasan industri, agribisnis dan agro industri, rekreasi dan pariwisata, serta kawasan pemukiman dan tempat pembuangan limbah (Dahuri, 2000).

Pada dasarnya, patut untuk kita bangga ketika Indonesia memiliki asset yang begitu melimpah. Garis pantai yang sangat panjang sekaligus wilayah pesisirnya, begitu pula dengan kepelbagaian hayati dan mineral (Anwar, R. K., Rusmana, A., \& Rahman, M. T., 2018). Namun semua itu akan menjadi malapetaka bagi masyarakat Indonesia, jika tidak dikelola dengan sebaik-baiknya. Dewasa ini, ketika persoalan agraria (dalam arti luas) menjadi isu penting, maka mulai-lah muncul kesadaran akan pentingnnya pembangunan yang lebih memfokuskan pada kelautan dan pesisir. Kehadiran Departemen Kelautan dan Perikanan (DKP) serta Kementrian Kemaritiman, diharapkan dapat berperan aktif dalam memajukan pembangunan baik pada insfraktukrur dan sumber daya masyakatnya.

Sektor kelautan dan perikanan perlu menjadi salah satu fokus kebijakan kemaritiman pemerintah. Selain itu, penting sebagai gambaran umum untuk menganalisis kehidupan masyarakat nelayan dalam menyusun kebijakan di sektor 
kemaritiman. Berdasarkan data Survei Sosial dan Ekonomi Nasional 2013, diketahui bahwa hanya 2,2 persen rumah tangga di Indonesia yang memiliki kepala rumah tangga berprofesi sebagai nelayan. Jumlahnya sekitar 1,4 juta kepala rumah tangga nelayan. Sementara secara keseluruhan jumlah masyarakat nelayan di Indonesia diperkirakan sebnyak 2,17 juta (Harmadi dalam Kompas 2014). Makna dibalik jumlah nelayan, Nelayan masih terjebak dalam perangkat kemiskinan, mereka tidak memiliki akses yang memadai terhadap pendidikan dan kesehatan. Mereka juga kesulitan mendapatkan akses kredit karena sebagain besar bank beranggapan bahwa pinjaman bagi nelayan dapat beresiko tinggi. Penyebab keberlanjutan kemiskinan masyarakat nelayan adalah banyaknya pembangunan-pembangunan yang hanya mementingkan tanpa memperhatikan lingkungan. Akhirnya berdampak terhadap masyarakat kecil yang memiliki ketergantungan terhadap sumber daya pesisir.

Program pembangunan perikanan, kelautan dan pesisir, ketika itu juga muncul beberapa beberapa isu tak sedap seputar kegagalan pemertintah dalam mengatur program pembangunan, sehingga kemudian memicu terjadinya konflik. Beberapa faktor yang mendukung terjadinya konlik menurut Soekanto (1995) dalam Satria (2015) adalah perbedaan individu, perbedaan budaya, perbedaan kepentingan dan perubahan sosial. Satria (2015), mengatakan bahwa konflik akan terjadi apabila masing-masing pihak tidak bisa menerima atau menghormati prinsip atau sistem nilai yang di miliki oleh pihak lain sehingga muncul keinginan untuk mengubah sistem nilai tersebut. Sebagai contoh revolusi yang dilakukan oleh beberapa negara karena memiliki perbedaan pandangan antara beberapa pihak. Revolusi bisa ditandai dengan ancamanancaman dan tindakan-tindakan yang dapat menghancurkan pihak lawan (Rahman, 2018). 


\section{ART IKEL}

Konflik nelayan kecil dan nelayan besar adalah soal perebutan akses sumber daya antara masyarakat lokal dan pebisnis. Semua pihak memiliki kepentingan masingmasing. Nelayan kecil mengakses laut karena persolan perut. Hal ini lah yang kemudiaan memicu terjadinya konflik antara kepentingan pebisnis dan nelayan dalam mengakses laut karena pihak-pihak tersebut memiliki perbedaan-perbedaan yang berbeda. Konflik teluk Jakarta yang hingga saat ini masih belum selesai, merupakan cerminan dari serangkaian panjang politik kepentingan yang dimainkan oleh aktoraktor berkepntingan. Konflik Teluk Jakarta merupakan konnfilik akibat diadakannya reklamasi.

Sektor kelautan dan perikanan sering menimbulkan terjadinya konflik, sebagai konsekuensi laut sebagai sumber daya yang bersifat open acces yang mengakibatkan terbukanya ruang untuk perbedaan kepentingan (Annisa 2009). Sifat open acess tersebut tidak lepas pemahama bahwa sumber daya alam adalah bersifat milik bersama (common pool resource), sehingga mendorong semua pihak untuk memanfaatkan sumber daya termasuk sumber daya perairan laut. Open acces adalah tidak adanya pihak yang bertanggungjwab dalam pemeliharaan kelestarian sumber daya (Priyatna 2013). Apabila terjadi Sumber daya alam yang terbatas jumlahnya dan dikuasai oleh semua orang dalam pemanfaatannya, dimana setiap individu memiliki rasionalitas memanfaatkan sumber daya alam secara terus-menerus, sehingga dapat menimbulkan akibat berkurangnya sumber daya alam dan setiap orang akan merugi inilah yang disebut (tragedy of the common) (Hardin 1968). Solusi dalam mencegah terjadinya "tragedy of the commons" yaitu; Pertama, pengelolaan sumber daya berada pada kepemilikan swasta (private proverty). Kedua, tetap menjadikan sumber daya alam sebagai barang milik publik (public property). Tetapi, dengan adanya pengaturan dan mengalokasikan hak-hak 


\section{ART IKEL}

tertentu untuk memasukinya, baik pengelolaan atau pemanfaatan sumber daya alam tersebut (Hardin 1968). Akan tetapi, ketika hak-hak penguasaan sumber alam sudah ada dan semakin jelas, permasalahan yang berkaitan dengan kerusakan sumber daya alam masih terjadi dan belum dapat di atasi.

Masalah ekologi tersebut bukanlah masalah teknis, tetapi lebih merupakan akibat dari tatanan politik dan ekonomi yang ada serta proses politik dari aktor-aktor yang berkepentingan. Inilah yang disebut Bryant dan Bailey (1997) sebagai bentuk "politicised environment" (Satria 2015). Aktor yang dominan umumnya adalah negara dan swasta besar, sehingga sumber daya yang melimpah dan berbagai konsep pembangunan di berbagai daerah termasuk pembangunan reklamasi Teluk Jakarta, telah mengakibatkan adanya ketidak merataan di antara aktor yang berkepentingan terhadap sumber daya pesisir. Akibatnya, masyarakat kecil kehilangan sumber mata pencahariannya. Pertanyaanya adalah pihak manakah yang mengalami kerugian paling buruk, siapa kah yang salah, apakah nelayan, ataukah pemerintab? A taukah mungkin ada yang salah dalam kebijakan? Karena seringkali politisasi itu berasal dari kebijakan yang salah (Rahman, MT, Sulthonie, AA, Solihin, S., 2018).

Permasalahan disini akan difokuskan pada aspek perubahan sosial-ekonomi masyarakat pesisir akibat pembangunan pelabuhan Muara Angke yang merupakan salah satu bagian dari kebijakan reklamasi Pantai Utara Jakarta, dampak sosial-ekonomi mulai muncul ketika terdapat aktivitas : proyek, program atau kebijaksanaan yang akan diterapkan pada suatu masyarakat. Bentuk intervensi ini mempengaruhi keseimbangan pada suatu sistem (masyarakat). Pengaruh yang ditimbulkan bisa bersifat positif, ataupun negatif. Perubahan yang dimaksud adalah beralihnya keadaan sosial-ekonomi masyarakat ketika sebelum adanya reklamasi hingga setelah reklamasi. Kemudian yang 
dimaksud dengan masyarakat pada penelitian ini adalah masyarakat pesisir yang mencari nafkah di sekitar wilayah penelitian, antara lain nelayan, pedagang dan pengolah ikan, pedagang dan pengolah kerang, dan mata pencaharian non perikanan. Sedangkan, aspek sosial-ekonomi difokuskan pada aspek-aspek yang dapat diukur (tangible), seperti pengalaman usaha, jumlah anggota keluarga, tingkat pendidikan, kondisi dan fasilitas perumahan, mata pencaharian, pendapatan rumah tangga dan pengeluaran rumah tangga.

\section{B. TINJAUAN TEORI}

Istilah reklamasi menurut Kamus Besar Bahasa Indonesia diartikan sebagai pengurukan (tanah), atau juga usaha memperluas pertanian (tanah) atau dengan memanfaatkan daerah yang sebelumnya tidak bermanfaat menjaddi bermanfaat. Menurut Undang-undang nomor 27 tahun 2007 tentang pengelolaan wilayah pesisir dan pulau-pulau kecil, mengungkapkan bahwa reklamasi adalah kegiatan yang dilakukan dalam rangka meningkatkan manfaat sumber daya lahan yang ditnjau dari sudut lingkungan dan sosial ekonomi dengan cara pengurugan, pengeringan dalahan atau drainase. Pengertian ini sejalan dengan Paeraturan Mentri Pekerjaan Umum no. 40/PRT/M/2007 mengenai Pedoman Perencanaan Tata ruang Kawasan Reklamasi Pantai. Reklamasi adalah usaha pembentukan lahan baru dengan cara pengurugan, pengeringan lahan atau drainase dalam rangka meningkatkan manfaat sumber daya lahan yang ditinjau dari sudut lingkungan dan sosial ekonomi. Seddangkan reklamasi pantai dapat diartikan sebagai usaha pemebentukan lahan baru baik yang menyatu dengan wilayah pantai ataupun yang terpisah dari panatai dengan cara pengurugan, pengeringan lahan atau dranase dalam rangka meningkatkan manfaat sumber daya lahan yang ditinjau dari sudut lingkungan dan sosial ekonomi. 
Perubahan pantai dan dampak akibat adanya reklamasi tidak hanya bersfat lokal. Reklamasi memiliki dampak positif dan negatif bagi masyarakat dan ekosistem pesisir dan laut. Dampak positif yaitu; sesuai dengan tujuan diadakannya reklamasi, seperti menghidupakan kembali transfortasi air, membuka peluang pembangunan wilayah pesisir, meningkatkan pariwisata bahari, serta meningkatkan pendapatan daerah. Kegiatan reklamasi dapat meningkatkan kualitas dan nilai ekonomi kawasan pesisir, mengurangi lahan yang dianggap kurang produktif, penambahan wilayah, perlindungan pantai dari erosi, peningkatan kondisi habitat perairan dan penyerapan tenaga kerja (Mustaqim 2015).

Terjadinya kondisi "tragedy of the common" didorong oleh kondisi sumber daya perikanan yang bersifat milik bersama (common pool resources). Status 'milik bersama' tersebut memiliki konsekuensi terhadap akses bagi pengelolaanya. Konsekuensi akses pengelolaan tersebut dapat bersifat ekslusif bagi kelompok tertentu atau seringkali bersifat open acces (Rahman, 2018). Permasalahan yang kemudian muncul akibat pengelolaan bersifat open access adalah tidak adanya pihak yang bertanggungjawab dalam pemeliharaan kelestarian sumber daya (Fatriyandi et al 2013). Menurut Hardin (1968) mengatakan bahwa sumber daya alam milik bersama dimana memiliki akses yang bebas dan tidak diatur akan mengakibatkan terjadinya tragedi untuk semua masyarakat (tragedy of the commons). Tragedi tersebut terjadi, karena pemanfaatan mengeksploitasi sumber daya alam sampai kepada titik maksimal, akhirnya menimbulkan terjadinya kerusakan dan akibatnya terjadi tragedi tersebut. untuk mencegah terjadinya sumber daya bersama atau bebas akses tanpa adanya aturan, menurut Hardin (1968) mengatakan bahwa untuk mencegahnya harus ada pengaturan yang sifatnya memaksa dan dapat 


\section{ART IKEL}

menumbuhkan rasa tanggungjawab. Pengaturan yang memaksa disini maksudnya adalah pengaturan yang disepakati bersama dalam memanfaatkan sumber daya.

Sumber daya alam tidak dapat lepas dengan permasalahan cara masyarakat dalam mendapatkan akses. akses masyarakat terhadap sumber daya alam haruslah dipandang sebagai kesatuan dalam sistem kepemilikan sumber daya yang ada didalam masyarakat. sistem hak kepemilikan sumber daya seringkali diartikan sebagai mekanisme sosial yang memberikan wewenang dan dapat mengikat individu dalam masyarakat dengan kepemilikan kewenangannya (Bromley 1991). Bromley dalam Satria (2009) mengatakan terdapat empat rezim kepemilikan sumber daya yaitu; pertama, Akses terbuka (open acces) dimana dalam rezim sumber daya akses terbuka, tidak ada pengaturan tentang apa, kapan, dimana, siapa, dan bagaimana sumber daya alam dimanfaatkan. Kedua, kepemilikan negara (state property), dimana rezim negara berada di tingkat daerah hingga pusat. Intervensi pemerintah adalah dalam pengaturan pengelolaan sumber daya yang bertujuan untuk tujuan alokasi, keadilan dan stabilitas yang bersifat formal. Ketiga, rezim swasta, baik individual maupun korporasi, biasanya dalam bentuk hak kepemilikan yang bersifat temporal (jangka waktu tertentu) karena izin pemanfaatan yang diberikan oleh pemerintah. Keempat, rezim komunal/masyarakat (communal property). Biasanya bersifat aturan turun temurun, lokal, dan spesifik. Aturanaturan pengelolaan biasanya tertulis dan tidak tertulis.

Pengertian akses sebagai bundle dan jaring kekuasaan yang memungkinkan aktor mendapatkan, mengendalikan, dan memelihara akses. Akses dapat diartikan sebagai suatu kemampuan untuk memperoleh keuntungan dari sesuatu. Misalnya mendapatkan keuntungan dari objek material, metrial, orang lain, lembaga, dan simbol. Pemahaman teori akses ini berbeda dengan pemahman akses konvensional 


\section{ART IKEL}

sebagaimana yang dikaji dalam property right. Toeri akses lebih fokus kepada kemampuan dibandingkan kepada hak. Selin itu, permasalahan akses dapat diketahui dalam berbagai tatanan hubungan sosial yang lebih luas (bundle of powers), sehingga aktor mampu memperoleh keuntungan dari sumber daya tanpa ada tidaknya hubungan hak menguasai (bundle of right) (Ribot dan Peluso 2003).. Akses dalam pemahaman teori Ribot dan Peluso menekankan atas kesatuan kekuasaan (bundle of powers). Kekuasaan tersebut dapat terbentuk melalui beberapa unsur seperti unsur kultural, materi, dan ekonomi politik.

Metode analisis akses yang disanrankan Ribot dan Peluso adalah suatu proses untuk mengidentifikasi dan memetakan mekanismes perolehan, pemeliharaan dan pengendalian akses. Menurut Ribot dan Peluso (2003) analisis akses melibatkan beberapa hal yaitu: Pertama, mengidentifikasi dan memetakan aliran keuntungan dari kepentingan masing-masing aktor. Kedua, mengidentifikasi mekanisme dimana aktor yang berbeda melibatkan perolehan, kontrol, dan pemeliharaan aliran keuntungan dan distribusinya. Ketiga, analisis hubungan kekuasaan yang mendasari mekanisme akses yang institusi-institusi dimana keuntungan diperoleh.

Ostrom (1990) meletakan dasar analisis kekuasaan terhadap akses sumber daya melalui pendekatan hak kepemilikan (property right), sehingga penekanan kekuasaan akses terhadap sumber daya alam adalah berdasarkan kepemilikan. Selanjutnya, arena kekuasaan terhadap sumber daya dapat ditentukan oleh (bundle of power). Kekuasaan yang ada pada aktor bisa dimanfaatkan untuk memengaruhi kemampuan seseorang dalam mengambil keuntungan atau akses terhadap sumber daya.

Asumsi Relasi kuasa Ostrom ditentukan oleh legitimasi: seperti hak kepemilikan menentukan kuasa aktor dan kuasa aktor bekerja tergantung kepada tipe- 


\section{ART IKEL}

tipe property right yang dimilikinya. Berbeda dengan Ostrom, dimana Asumsi relasi kuasa Ribot dan Peluso adalah relasi kuasa terjadi tidak hanya ditentukan oleh seperangkat hak; seperti adanya kemampuan aktor dalam jejaring kekuasaan aktor dalam menentukan akses dan kuasa dominasi dimana kuasa aktor dapat dijalankan dalam berbagai strategi seperti lobi politik dan materi. Selain itu, gambaran relasi kekuasaan pada masyarakat nelayan tidak bisa lepas dari ciri umum struktur sosial masyarakat pesisir dimana umumnya berccirikan ikatan patron-klien.

Terjadinya konflik yang diakibatkan oleh relasi kekuasaan yang tidak setara dalam pemanfaatan sumber daya perairan laut, yang tercermin dalam berbagai kebijakan pemerintah. Bryant (1998), memahami hubungan kekuasaan yang tidak setara merupakan dampak dari politisasi lingkungan (politicized environment). Perhatian Bryant dan Bailey (1997) tertuju kepada aktor-aktor, aktor-aktor tersebut yaitu; negara, pengusaha, institusi multilateral, NGO, dan masyarakat. Relasi kekuasaan di antara aktor dapat dieksplorasi mulai dari posisi, peran, kepentingan, dan berbagai tindakan yang dilakukan oleh aktor yang berbeda.

Tindakan-tindakan aktor tersebut berkaitan dengan akses yang dimiliki oleh setiap aktor. Akses sebagai kemampuan untuk memperoleh keuntungan dari sesuatu, termasuk obyek material, orang, kelembagaan, dan simbol (Ribot dan Peluso 2003). Kemampuan tersebut terkait dengan kekuatan atau kekuasaan. Kekuasaan melekat dan dilaksanakan melalui berbagai mekanisme, proses dan relasi sosial, dimana penguasaan teknologi, modal, pasar, tenaga kerja dan peluang tenaga kerja, pengetahuan, kewenangan, identitas sosial dan relasi sosial (bundle of power) akan mempengaruhi tingkat akses terhadap sumber daya alam (Ribot dan Peluso 2003). Artinya, semakin 
besar kekuasaan yang dimiliki oleh aktor, maka akan semakin besar aksesnya terhadap sumber daya peraran laut termasuk dalam pengelolaan dan pemanfaatannya.

\section{METODE}

Analisis mengenai perspektif ekologi politik dalam memahami kemiskinan nelayan kecil karena akibat adanya pembangunan reklamasi di Pantai Utara Jakarta atau teluk Jakarta ini adalah analisis kualitatif. Kemudian, dalam hal sumber data, analisis penelitian ini menggunakan studi kepustakaan yang dilakukan pada berbagai sumber, seperti jurnal, buku, tesis, disertasi, dan Koran (media massa cetak). Lokasi yang menjadi analisis penelitian adalah seluruh wilayah Pantai Utara Jakarta yang mendapatkan dampak dari adanya pembangunan reklamasi.

\section{HASIL DAN PEMBAHASAN}

\section{A. Pantai Utara Jakarta dan Analisis Aktor}

Wilayah Teluk Jakarta meliputi daerah pesisir Jakarta dan Perairan Teluk Jakarta yang dibatasi oleh Tanjung Pasir di sebelah Barat (600,96’ LS/10647,76’ BT)

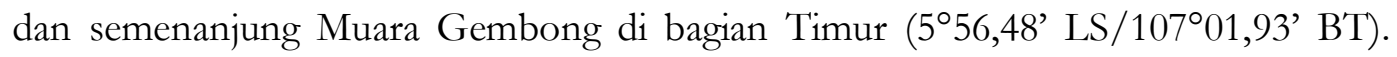
Wilayah ini merupakan teluk yang dangkal dengan profil kedalaman 5 meter terpisah jarak $1 \mathrm{~km}$ dari pantai, kemudian kontur kedalaman 10 meter pada jarak $3 \mathrm{~km}$ dari pantai. Luas keseluruhan perairan Teluk Jakarta adalah $514 \mathrm{~km}^{2}$, dengan panjang garis pantai sekitar $72 \mathrm{~km}$. Teluk Jakarta ini telah mengalami perubahan akibat pembangunan pesisir yang sangat signifikan dalam kurun waktu beberapa dekade terakhir ini, dan masih banyak lagi sejumlah proyek pembangunan yang akan diusulkan maupun tengah sedang berlangsung yang bakal memberikan dampak serius.

Jakarta yang merupakan ibu kota negara kondisinya sangat padat dengan luas daratan yang terbatas, sehingga untuk memenuhi kebutuhan lahan bagi pembangunan 


\section{ART IKEL}

serta perluasan kawasan Jakarta maka pilihan yang tidak bisa dihindari adalah kegiatan reklamasi Teluk Jakarta. Selain untuk mengatasi keterbatasan lahan tersebut, kegiatan reklamasi pantai ini juga akan dapat memainkan peran yang sangat penting dalam penataan ulang dan dapat memberikan karakter tersendiri terhadap Kawasan Pantai Ancol dalam rangka pembangunan Jakarta Water Front City.

Salah satu kegiatan yang paling merasakan dampak akibat adanya reklamasi Teluk Jakarta adalah kegiatan perikanan. Populasi penduduk yang bekerja di bidang perikanan di Jakarta pada tahun 2009 adalah 2.366 pemilik perahu dan 16.581 buruh. Berdasarkan status penduduk di Jakarta terdapat 10.268 nelayan tetap dan 8.678 nelayan pendatang. Populasi nelayan yang tinggi telah mengakibatkan fasilitas dan infrastruktur yang tersedia tidak mencukupi termasuk perumahan bagi para nelayan, sehingga sisi kanal-kanal untuk perbaikan kapal telah digunakan juga untuk pemukiman. Aktifitas perikanan saat ini didominasi oleh mini purse seine (payang), purse seine, jaring rampus, jaring insang, bagan dan perangkap (bubu). Ikan yang menjadi target penangkapan diantaranya ikan baronang, kerapu, belanak, julung-julung, cendro dan sebagainya. Selain jenis ikan, kerang hijau merupakan salah satu komoditas yang banyak dibudidayakan di perairan pesisir Utara Jakarta.

Wilayah Teluk Jakarta meliputi daerah pesisir Jakarta dan Perairan Teluk Jakarta yang dibatasi oleh Tanjung Pasir di sebelah Barat (600,96’ LS/10647,76’ BT)

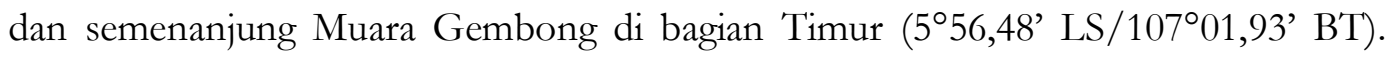
Wilayah ini merupakan teluk yang dangkal dengan profil kedalaman 5 meter terpisah jarak $1 \mathrm{~km}$ dari pantai, kemudian kontur kedalaman 10 meter pada jarak $3 \mathrm{~km}$ dari pantai. Luas keseluruhan perairan Teluk Jakarta adalah $514 \mathrm{~km}^{2}$, dengan panjang garis pantai sekitar $72 \mathrm{~km}$. Teluk Jakarta ini telah mengalami perubahan akibat 
pembangunan pesisir yang sangat signifikan dalam kurun waktu beberapa dekade terakhir ini, dan masih banyak lagi sejumlah proyek pembangunan yang akan diusulkan maupun tengah sedang berlangsung yang bakal memberikan dampak serius.

Selama satu dasawarsa terakhir, wacana reklamasi Teluk Jakarta semakin kencang. Berbagai kebijakan pemerintah muncul, ada yang melarang, tetapi tak jarang melegalkan reklamasi. Belakangan, wacana tersebut menguat, dihadirkan dengan mengusung tujuan mulia menambah luasan Jakarta sebagai antisipasi perkembangan ibu kota negara. Reklamasi bukan hal baru bagi Jakarta. Kegiatan untuk meningkatkan manfaat sumber daya lahan dengan pengurukan dan pengeringan lahan atau drainase tersebut sudah mulai dilakukan sejak 1980-an.

PT Harapan Indah mereklamasi kawasan Pantai Pluit selebar 400 meter dengan penimbunan. Daerah baru yang terbentuk digunakan untuk permukiman mewah Pantai Mutiara. Dalam catatan pemberitaan Kompas, PT Pembangunan Jaya melakukan reklamasi kawasan Ancol sisi utara untuk kawasan industri dan rekreasi sekitar tahun 1981. Sepuluh tahun kemudian, giliran hutan bakau Kapuk yang direklamasi untuk kawasan permukiman mewah yang sekarang dikenal dengan sebutan Pantai Indah Kapuk. Tahun 1995, menyusul reklamasi yang digunakan untuk industri, yakni Kawasan Berikat Marunda (Kompas 11/11/2015).

Kegiatan reklamasi di empat lokasi tersebut sudah menimbulkan perdebatan. Sejumlah pihak menuduh reklamasi Pantai Pluit mengganggu sistem PLTU Muara Karang. Diduga, ini terjadi akibat adanya perubahan pola arus laut di areal reklamasi Pantai Mutiara yang berdampak terhadap mekanisme arus pendinginan PLTU. Tak hanya itu, tenggelamnya sejumlah pulau di perairan Kepulauan Seribu diduga akibat dari pengambilan pasir laut untuk menimbun arealreklamasi Ancol. Akan tetapi, 


\section{ART IKEL}

dampak negatif tersebut tidak diperhatikan. Upaya reklamasi dipilih untuk menambah luas daratan ibu kota negara.

Wiyogo Atmodarminto, Gubernur DKI Jakarta waktu itu, menyatakan reklamasi ke utara Jakarta dipilih karena perluasan ke arah selatan sudah tidak memungkinkan lagi. Rencana reklamasi seluas 2.700 hektar tersebut pertama kali dipaparkan di hadapan Presiden Soeharto, Maret 1995. Selain untuk mengatasi kelangkaan lahan di Jakarta, proyek reklamasi juga untuk mengembangkan wilayah Jakarta Utara yang tertinggal dibandingkan empat wilayah lain. Untuk memuluskan rencana tersebut, disahkan Keputusan Presiden Nomor 52 Tahun 1995 tentang reklamasi Pantai Utara Jakarta dan Perda Nomor 8 Tahun 1995.

Rencana reklamasi sudah dimulai sejak lama dan pada era Soeharto. Pernyataan tersebut, didukung dengan diterbitkannya aturan-aturan yaitu; pertama, pada tahun 1995 menerbitkan aturan; Keppres No. 52 Tahun 1995 tentang Reklamasi Pantai Utara Jakarta. Selain itu, Perda No. 8 Tahun 1995 tentang Penyelenggaraan Reklamasi dan Rencana Tata Ruang Kawasan Pantura Jakarta. Kedua, tahun 1996 telah terbit aturan; SK. Gubernur KDKI Jakarta No. 1090 Tahun 1996 tentang Organisasi Dan Tata Kerja Badan Pengendali Reklamasi Pantura Jakarta. Ketiga, pada tahun 1997 dimana telah terbit aturan; Kepmeneg Perencanaan Pembangunan Nasional/Ketua Bappenas No. KEP.920/KET/10/1997 tentang Pedoman Penataan Ruang Kawasan Pantai Utara.

\section{Analisis Aktor Pemerintah}

Pengembangan reklamasi kawasan Pantai Utara Jakarta, terkait dengan upaya mewujudkan cita-cita Jakarta sebagai kota jasa berskala international. Adanya aturanaturan yang berkaitan dengan pembangunan reklamasi, menandakan bahwa, pelaksanaan reklamasi di kawasan Pantai Utara Jakarta telah memiliki payung hukum. 


\section{ART IKEL}

Akan tetapi, pengembangan kawasan Pantai Utara Jakarta tidaklah mudah mengingat karakteristik pengembangannya yang membutuhkan modal yang sangat besar. Adanya bentuk keterbatasan tersebut, maka pihak pemerintah provinsi DKI Jkarta bekerja sama dengan pihak swasta untuk berpartisipasi dalam mewudujkan rencana reklamasi Kawasan Pantai Utara Jakarta.

Peran pemerintah dalam pembangunan reklamasi teluk Jakarta, sangat mempengaruhi berbagai pembangunan yang berkaitan dengan reklamasi. Melalui kebijakan pemerintah pembangunan tersebut dapat dikendalikan melalui pihak swasta. Kebijakan-kebijakan pemerintah sejak masa orde baru sampai masa reformasi masih belum terlaksana, penyebabnya pemerintah dengan berbagai aturannya, masih belum mampu meyakinkan masyarakat nelayan yang sangat ketergantungan terhadap sumber daya alam. Selain itu, isu kerusakan lingkungan semakin ramai diperdebatkan, karena isu tersebut berkaitan dengan keberlanjutan sumber daya. Apabila, keberlanjutan sumber daya perairan laut terganggu dan mengalami kerusakan, maka yang akan mengalami kerugian semua oarang termasuk pemerintah dan pihak swasta.

\section{Analisis Aktor Swasta}

Sejak tahun 1997 telah banyak dokumen kerja sama yang dtandatangani anatara pemerintah Provinsi DKI Jakarta dengan pihak swasta yang berniat melaksanakan reklamasi kawasan panatai Uatara Jakarta seperti PT Kapuk Naga Indah, PT Jakarta Prepertindo, Pt Muara Wisesa Samudra, Pt Bhakti Bangun Eramulia, PT Taman Harapan Indah, PT Ismac, PT Pembangunan Jaya Ancol, Pt Jaladri Kartika Paksi, PT Manggala Krida Yudha, dan PT Pelindo II. Dokumen kerja sama tersebut meliputi berbagai bentuk seperti Nota Kesepahaman (MoU), Development Agreement (DA), maupun Perjanjian Kerja sama (PKS) (Indraka). Faktanya kegiatan reklamasi Kawasan 


\section{ART IKEL}

Pantai Utara Jakarta tidak terwujud sesuai harapan. Hanya PT Taman Harapan Indah (pantai mutiara) yang telak melaksankan reklamasi. Faktor-faktor yang mempengaruhi belum terwujudnya reklamasi menurut Budiharjo dalam (Indraka 2012) yaitu: terjadinya krisis ekonomi pada tahun 1998 yang menyebabkan berbagai biaya produksi, Badan Pelaksanaan Reklamasi Pantai Utara Jakarta kurang mampu mendorong pihak swasta yang telah memiliki dokumen kerjasama pengembangan dengan Provinsi DKI Jakrta, serta belum adanya aturan main yang jelas dan tegas untuk mengendalikan kerja sama dengan pihak swasta.

\section{Analisis Aktor LSM}

Proyek reklamasi 17 pulau buatan di Pantai Utara Jakarta yang menuai pro dan kontra, sehingga tidak bisa lepas, termasuk organisasi Lembaga Sosial Masyarakat (LSM). Penolakan keras datang dari Kesatuan Nelayan Tradisional Indonesia (KNTI), Koalisis Keadilan Perikanan (KIARA), dan Wahana Lingkungan Hidup Indonesia (WALHI) yang didukung oleh Indonesia Center for Environmental Law dan Lembaga Bantuan Hukum Jakarta. Alasan penolakan terhadap pembangunan reklamasi yaitu: pembangunan reklamasi diyakini dapat membahayakan berbagai ekosistem mangrove dan padang lamun di sekitar wilayah reklamasi, sehingga akhirnya dapat menghambat masyarakat nelayan yang memiliki kepentingan dan ketergantungan terhadap sumber daya perairan laut di wilayah pembangunan reklamasi teluk jakarta.

\section{Analisis Aktor Masyarakat Nelayan}

Jakarta yang merupakan ibu kota negara kondisinya sangat padat dengan luas daratan yang terbatas, sehingga untuk memenuhi kebutuhan lahan bagi pembangunan serta perluasan kawasan Jakarta maka pilihan yang tidak bisa dihindari adalah kegiatan reklamasi Teluk Jakarta. Selain untuk mengatasi keterbatasan lahan tersebut, kegiatan 
reklamasi pantai ini juga akan dapat memainkan peran yang sangat penting dalam penataan ulang dan dapat memberikan karakter tersendiri terhadap Kawasan Pantai Ancol dalam rangka pembangunan Jakarta Water Front City. Keseluruhan rangkaian kegiatan tersebut merupakan suatu proses pembangunan.

Pembangunan merupakan suatu proses perubahan sosial yang bertujuan untuk meningkatkan taraf hidup manusia dengan melakukan aktivitas pemanfaatan sumber daya alam. Menurut Garna (1992:1) perubahan sosial terjadi karena adanya proses pembangunan yang dilakukan, baik oleh masyarakat itu sendiri maupun dari luar masyarakat. Perubahan sosial yang terjadi di Indonesia, pada umumnya merupakan proses yang terkendali oleh pola perencanaan yang disebut 'pembangunan'.

Reklamasi teluk Jakarta merupakan suatu bentuk dari pembangunan yang di programkan oleh pemerintah dengan memanfaatkan luas wilayah teluk Jakarta. Pemerintah terus menurus mendorong pembangunan kawasan laut, namun mereka lupa jika pembangunan tersebut disisi lain sedang menjadikan proses kemiskinan baru pada masyarakat nelayan. Masyarakat nelayanan kehilangan mata pencaharian mereka, kehilangan juga pola nafka mereka, masyarakat juga kehilangan mengakses sumber daya alam yang telah menghidupkan mereka dari generasi-generasi sebelumnya. Contoh kasus dapat dilihat pada suku Marind anim di Merauke. Program swasembada pangan (MIFFE) memberikan iming-iming tentang suatu pembangunan. Lantas yang terjadi, masyarakat malah kehilangan akses mereka pada hutan. Mata pencaharian mereka hilang, dan ketika tidak ditemukan titik terang, maka saat itulah pemberontakn dan konflik di mulai.

Dalam Pengantar Sosiologi Masyarakat Pesisir hal. 92 (satria 2015) menganalogikan kemiskinan pada masyarkat Indonesia, ibarat tikus mati di lumbung 
padi. Negara ini memiliki sumber daya yang begitu banyak namun masyarakatnya menderita dan miskin. Lantas kemiskinan-kemiskinan tersbut diakibatkan siapa ? apakah karena nelayan tidak mampu mentransformasikan diri mereka menjadi nelayan tanggu ? atau kah pemerintah yang salah karena tidak memberikan kesempatan bagi masyarakat lokal dalam bertranformasi ?. Satria (2015) mengatakan bahwa kemiskinan dapat dilihat dengan menggunakan dua pendekatan, yang pertama adalah moderenisasi dan structural. Pendekatan moderenisasi selalu melihat bahwa kemiskinan pada masyarakat terjadi karena faktor internal masyarakat sendiri. Kedua adalah pendekatan structural. Menurut pendekatan sturuktural, kemiskinanan pada masyarakat terjadi akibat faktor-faktor eksternal, misalnya : belum adanya dukungan politik pada nelayan kecil.

Merujuk dari Satria (2015) bahwa, dari kedua pendekataan tersebut, pendekataan structural lebih mendekati kenyataan. Bahwa nelayan-nelayan kita di Indonesia bukan tidak mau maju (termasuk nelayan Jakarta Utara). Untuk memajukan nelayan-nelayan kecil tersebut seharunyanya politik memberikan dukungan penuh kepada masyarakat nelayan kecil, artinya perlu kebijakan-kebijakan afirmatif yang secara rill bekerja mendorong nelayan untuk melakukan mobolisasi vertikal.

\section{E. PEMBAHASAN}

Ketika kita melihat penyebab kemiskinan pada nelayan kecil, belum tentu masalah itu selesai dengan sendirinya, ada hal paling penting untuk dapat dibahas, yaitu tentang bagaimana mengelolah sumber daya alam untuk keberlangsungan semua pihak. Tetapi perlu diketahui bahwa, proses mengakses sumber daya alam, tetnutnya masyarakat harus memiliki Power. Ostrom (1990) meletakan dasar analisis kekuasaan terhadap akses sumber daya melalui pendekatan hak kepemilikan (property right), 
sehingga penekanan kekuasaan akses terhadap sumber daya alam adalah berdasarkan kepemilikan. Selanjutnya, arena analisis kekuasaan menurut Ribot dan Peluso (2003) berbeda dengan Ostrom dimana kekuasaan terhadap sumber daya dapat ditentukan oleh (bundle of power). Kekuasaan yang ada pada aktor bisa dimanfaatkan untuk memengaruhi kemampuan seseorang dalam mengambil keuntungan atau akses terhadap sumber daya.

Isu tentang pengolahan sumber daya kini makin menarik karena ketika pengolahan sumber daya tidak dilakukan dengan baik maka akan timbul berbagai masalah dalam tatanan masyarakat. Oleh karenanya untuk pengelolahan sumber daya maka penting untuk mengkaji pelaku-pelaku yang mengambil bagian dalam proses pengolahan sumber daya alam. Jentof (1989) dalam (Satria 2015) mendefinisikan tiga bentuk pendekatan dalam pengendalian stakeholder, diantanya adalah government (command and control), community based management, dan co-Management.

Model yang pertama adalah government (command and control) pada tahapan ini, pemerinta mengambil ahli semua Kontrol dan pengelolahan. Nelayan dan pelaku usaha tidak berpartisipasi dalam mengelolah dan mengontrol suberdaya alam. Pendekatan ini pun diyakini memiliki beberapa kelemahan (Satria, 2015). Model yang kedua adalah community based management. Proses ini merupakan suatu perbaikan dari tahapan awal, karena control oleh pemerintah atas sumber daya dianggap masih memiliki banyak kelemahan. Pada tahap ini, masyarakatlah yang mengolah segala macam sumber daya berdasarkan pola-pola yang terbangun dalam komunitas masyarakat, pada model ini terlihat jelas bahwa masyarakat memiliki rasa tanggung jawab terhadap perubahanperubahan pada sumber daya alam. 
Model yang terakhir adalah model ko-managemen, model ini merupakan penggabungan dari kedua model sebelumnya, yaknin pendekatan yang terjadi akibat kolaborasi antara pemerintah dan masyarakat. Pada model ini masyarakat dan pemerintah bekerja sama untuk menjaga kerusakan sumber daya. Setelah membahasa model-model pendekatan pengendalian stakeholder, maka persolana reklamasi di Jakarta dapat diatasi dengan pendekatan atau pengolahan berbasis aktor. Model yang paling mungkin dapat bisa dipakai adalah dengan pendekatan community based management, dan co-Management. Sehingga masyarakat dapat mengangkat kearifan-kearifan mereka untuk menjaga kelestarian, sekaligus dapat berkolaborasi dengan pemerintah untuk mendukung beberapa regulasi yang berpihak pada nelayan kecil.

\section{F. KESIMPULAN}

Masyarakat nelayan kecil di teluk Jakarta dapat dilihat sebagai masyarakat yang berada pada lapisan bawah karena minim kekuatan. Oleh karenanya, nelayan kecil tidak dapat berbuat apa-apa ketika wilayah laut mereka dirubah menjadi wilayah reklamasi. Akibatnya tentu jelas, nelayan kecil kehilangan mata pencaharian mereka, kehilangan akses ke laut, dan kerugian-kerugian lainya yang bersangkutan dengan akses sumber daya. Untuk membahas bagaimana jalan keluar yang baik antara aktor-aktor yang berkepentingan tersebut, maka yang utama harus dilakukan adalah menyangkut tata cara pegelolaan. Pengolaan sumber daya alam perikanan (fishiers management) merupakan upaya penting dalam menjaga kesinambungan sumber daya (sustainability). Dengan demikian tidak saja generasi sekarang yang menikmati kekayaan sumber daya, tetapi generasi mendatang pun akan merasakan hal yang sama. 


\section{ART IKEL}

\section{DAFTAR PUSTAKA}

Anwar, R. K., Rusmana, A., \& Rahman, M. T. 2018. The Politics Of Information On Traditional Medical Practices In Bandung Barat. MIMBAR, Vol. No 1st (June) 2018 pp. 158-165, 34(1).

Dahuri, Rokhmin. 2000. Pendayagunaan Sumber Daya Kelautan untuk Kesejabteraan Rakyat. Jakarta: Lembaga Informasi dan Studi Pembangunan Indonesia.

Hafsanita SD. 2008. Persepsi Nelayan Terbadap Potensi Dampak Reklamasi Pantai Utara Jakarta (Tesis). Yogyakarta (ID): Universitas Gajah Mada.

Harmadi, Sonny Harry B. Nelayan Kita. HU. Kompas, 19 November 2014 https://nasional.kompas.com/read/2014/11/19/21243231/Nelavan.Kita [19/1/2019].

Indraka R. 2012. Penentuan Insentif dalam Pengembangan Reklamasi Kawasan Pantai Utara Jakarta (Tesis). Jakarta (ID): Universitas Indonesia.

Kardono, Priyadi. 2015. Garis Pantai Indonesia terpanjang Kedua di Dunia, Antara News.com.

Mustaqim I. 2015. Dampak Reklamasi Pantai Utara Jakarta Terhadap Perubahan Sosial Ekonomi Masyarakat. Jakarta (ID): Universitas Islam Negeri syarif Hidayatullah Jakarta.

Ostrom E. 1990. Governing The Commons: The Evolution of Institutions for Collective Action. Cambridge (GB): Cambridge University Press.

Priyatna FN. 2013. Kontestasi Kepentingan Dalam Pengelolaan sumber daya Perairan Waduk Djuanda, Jatilubur. (Tesis). Bogor (ID): Institut Pertanian Bogor.

Rahman, M. Taufiq. 2018. Pengantar Filsafat Sosial. Bandung: Lekkas. 
Rahman, M.T., Sulthonie, A.A. and Solihin, S., 2018. “Sosiologi Informasi Pengobatan Tradisional Religius" Kajian di Masyarakat Perdesaan Jawa Barat. Jurnal Studi Agama dan Masyarakat, 14(2), pp.100-111.

Ribot CJ \& Peluso NL. 2003. A Theory of Access. Rural Sociology, Vol. 68, No. 2, Juni 2003.

Satria A. 2009. Ekologi Politik Nelayan. Yogyakarta (ID): LKiSYogyakarta.

Satria A. 2015. Pengantar Sosiologi Masyarakat Pesisir. Jakarta (ID): Yayasan Pustaka Obor Indonesia.

Satria A. 2015. Politik Kelautan dan Perikanan: Catatan Perjalanan Kebijakan Era SBY bingga Jokowi. Jakarta (ID): Yayasan Pustaka Obar Indonesia.

Supono S. 2009. Model Kebijakan Pengembangan Kawasan Pantai Utara Jakarta Secara Berkelanjutan. (Disertasi). Bogor (ID): Institut Pertanian Bogor. 